Egyptian Journal of Aquatic Biology \& Fisheries

Zoology Department, Faculty of Science,

Ain Shams University, Cairo, Egypt.

ISSN $1110-6131$

Vol. 23(3): 589 - 598 (2019)

www.ejabf.journals.ekb.eg

\title{
Role of dietary L-carnitine supplements on improving of reproductive performance of Nile tilapia (Oreochromis niloticus)
}

\author{
Ahmed F. Fath El-Bab ${ }^{1}$, Mostafa. M. El-Moghazy ${ }^{1}$, Mohammed A. A. Mostafa ${ }^{2}$ \\ and Nayera M. S. El-Dweny ${ }^{1}$ \\ 1- Animal production, Faculty of Agriculture, Damietta University, Egypt. \\ 2- Central Laboratory for Aquaculture Research at Abbassa, ARC, Egypt \\ *Corresponding Author: ah_farouk74@yahoo.com
}

\section{ARTICLE INFO \\ Article History: \\ Received: Aug. 21, 2019 \\ Accepted: Sept. 18, 2019 \\ Online: Sept. 20, 2019}

\section{Keywords:}

L-carnitine

reproductive performance growth performance

Nile tilapia

O. niloticus

\section{ABSTRACT}

Studies on the effect of dietary L-carnitine supplements on reproductive performance for Oreochromis niloticus are scarce. A Seven months feeding trial was undertaken to examine four L-carnitine levels (control, 300, 600 and $900 \mathrm{mg} \mathrm{kg} 1 \mathrm{diet}$ ) on the reproductive performance for Oreochromis niloticus females and their fries during whole hatching season. A 120 females for were randomly distributed into 4 ponds (30 females per pond) represent four treatments and 4 ponds for the fry produced. During of this study, the reproductive traits for females and growth performance for fries were recorded. It was found that the dietary Lcarnitine supplementation at all levels $\left(300,600\right.$ and $900 \mathrm{mg}^{-1} \mathrm{~kg}$ ) significantly $(\mathrm{P}<0.01)$ increased all reproductive performance parameters (females weight $(\mathrm{FW})$, total egg weight per female $(\mathrm{EW} / \mathrm{F})$, egg weight $(\mathrm{g})$ per gm of body weight (EW/GF), Absolute and relative fecundity (ABS) and (REL), The ratio of number of eggs / one gram of egg (NE/GE), Hatchability percentage (Hat\%), Fry number per fish (FN/F) and Fry number per gram of female body weight (FN/GF)), also, increased all growth performance parameters for fries produced (body weight, daily weight gain and specific growth rate). and improved feed conversion ratio (FCR) and protein efficiency ratio (PER).

\section{INTRODUCTION}

One of the basic requirements of intensive farming of any fish species is a constant supply of good quality for eggs and fry from females. Commercial growers should be able to program the timing and the magnitude of spawning to fit with their hatchery and grow out fish requirements (Hebisha and Fathi, 2014).

The reproductive traits of Nile tilapia include many aspects like absolute fecundity, relative fecundity, gonads weight, egg weight, Ganado-somatic index (GSI), and fry performance (Bhujel, 2000; Gómez-Márquez et al., 2003; Mohamed et al., 2014).

As there are wide contrasts in the reproductive performance among species and individuals within the species (Kirpichnikov, 1981; Macaranas et al., 1997), many studies had been conducted to investigate different factors involved in tilapia reproductive performance. Some studies reported different relationships between females' weight and absolute fecundity (Kariman et al., 2008); relative fecundity 
(Farag, 2003); ovaries weight; GSI (Mohamed et al., 2014) and egg weight (Fath ElBab et al., 2011). Moreover, other studies reported some effects of female size on fry production performance of Oreochromis (Bhujel, 2000; El-Saidy and Gaber, 2005 and Mohamed et al., 2014).

L-carnitine (4-N-trimethylammonium-3-hydroxybutyric acid) is one of the multi-physiological, bioactive and pollution-free additives known to work as a growth, reproduction and hatching rate improver as a powerful cute for fish and crustaceans through better feed conversion and/or increased feed intake (Mohseni et al., 2008). L-carnitine is synthesized from two of the essential amino acids lysine (peptide-bound) and methionine with the assistance of ascorbic acid (vitamin c) and other secondary compounds produced in the body (Harpaz, 2005). as well, during lipid catabolism, L-carnitine is required for the transfer of medium and long-chain fatty acids from the cytosol to the mitochondria for energy production (Ozorio et al., 2002). inasmuch L-carnitine increasing lipids oxidation, it perhaps permits the use of high-fat diets by reducing the lipid accumulation in tissues. according to that, improvement in growth rates should be observed. Over the last years, evidence has been provided both to favor (Mohseni and Ozorio 2014). and reject this hypothesis (Rodehutscord, 1995; Ji et al., 1996). The improved energy production in mitochondria through â-oxidation of fatty acids may proposed that exogenous administration of L-carnitine could enhance the growth and reproductive traits of fish by improving energy utilization efficiency from lipid oxidation (Chatzifotis et al., 1995). L-carnitine could catalyze some specific cell roles and may impact several biochemical and physiological process during reproduction periods (Chatzifotis et al., 1995). as well, supplementation of dietary L-carnitine significantly improved survival rates and reproduction of Nile tilapia during overwintering period (Soltan et al., 2015).

This study aimed to investigate the effects of L-carnitine different levels on different reproductive performance aspects and fry performance of Nile tilapia in order for determine the optimum breeding stocks management that may improve hatcheries production for the commercial scale.

\section{MATERIALS AND METHODS}

\section{Location:}

The present study was carried out on groups (males and females) of Nile tilapia (Oreochromis niloticus) at the Fish Hatchery of Al-Manzalah Integrated fish Farm, General Authority for Fish Resources Development, Ministry of Agriculture. AlManzalah Integrated fish Farm located in southern of Al-Manzalah city, Dakahlia governorate.

\section{Experimental design:}

Ten concrete ponds in this experiment $\left(2.5 \times 10 \times 1 \mathrm{~m}^{3}\right)$ were divided into four ponds for the four different treatments control, 300, 600 and $900 \mathrm{mg} \mathrm{L}$ - carnitine and two ponds for the replacement of females after the hatching and four ponds for their fry produced. The females and males were stocked in these tanks (30 females and 10 males $3: 1$, respectively per pond). Each pond was filled with $17.5 \mathrm{~m}^{3}$ water from Bahr Hadous drain.

\section{Preparation of diets and feeding practices:}

The experimental fish were conducted to 4 treatment according to rate of LCarnitine in diets (control, 300, 600 and 900mg L-carnitine) during hatching season. The fish were fed commercial floating diet to keep the diets available for fish contain 
and about $3200 \mathrm{Kcal} / \mathrm{Kg}$ metabolizable energy (ME) for males and females (pellets $3 \mathrm{~mm}$ in diameter) at a daily rate of 5\% of total biomass for 6 days / week twice daily at 9.00 am and $3.00 \mathrm{pm}$ (Table 1).

Table 1: Composition of groups diets used during the experimental period.

\begin{tabular}{lcccc}
\hline Feed ingredients & \multicolumn{3}{c}{ Experimental diets } \\
\cline { 2 - 5 } & Diet1 & Diet2 & Diet3 & Diet4 \\
\hline Fish meal (72\%) & 14 & 14 & 14 & 14 \\
Soybean meal (44\%) & 40 & 40 & 40 & 40 \\
Yellow corn & 25.50 & 25.20 & 24.9 & 24.60 \\
L-carnitine & 0 & 0.30 & 0.60 & 0.90 \\
Rice bran & 15 & 15 & 15 & 15 \\
Fish oil & 2.5 & 2.5 & 2.5 & 2.5 \\
Vit. \& Min. mixture1 & 3 & 3 & 3 & 3 \\
\hline Sum & 100 & 100 & 100 & 100 \\
\hline Proximate analysis (dry matter basis) & & & 31.096 & 31.0715 \\
Crude protein (CP) & 31.11 & 31.1205 & 7.86 & 8.83 \\
Ether extract (EE) & 8.09 & 7.92 & 10.26 & 10.17 \\
Crude fiber (CF) & 10.19 & 9.98 & 11.05 & 11 \\
Ash & 11.16 & 11.08 & 3181 & 3175 \\
Digestible energy (Kcal/kg) & 3216 & 3192 & & \\
\hline
\end{tabular}

The larvae produced were abandoned to complete absorption of yolk-sac. After 2 days from hatching, the fries were stocked in the ponds corresponding to weight of females (each pond $3 \times 10 \times 1 \mathrm{~m}^{3}$ ). And the fry granules diet $40 \%$ crude protein and about $2900 \mathrm{Kcal} / \mathrm{Kg}$ (ME) (Table 2) was and offered at a daily rate $20 \%$ of total biomass put in dishes of floating (three times $9.00 \mathrm{am}, 1.00 \mathrm{pm}$ and $5.00 \mathrm{pm}$ ) for 30 days. Every 10 days, fry groups were randomly obtained from each pond then weighted and amount of feed was adjusted according to the changes in body weight throughout the experimental period.

Table 2: Composition of fry diets used during the experimental period.

\begin{tabular}{|c|c|c|c|c|}
\hline \multirow[t]{2}{*}{ Feed ingredients } & \multicolumn{4}{|c|}{ Experimental diets } \\
\hline & Diet1 & Diet2 & Diet3 & Diet4 \\
\hline Fish meal $(72 \%)$ & 26 & 26 & 26 & 26 \\
\hline Yellow corn & 13.5 & 13.20 & 12.90 & 12.60 \\
\hline Soybean meal (44\%) & 40 & 40 & 40 & 40 \\
\hline L-carnitine & 0 & 0.30 & 0.60 & 0.90 \\
\hline Rice bran & 15 & 15 & 15 & 15 \\
\hline Fish oil & 2.5 & 2.5 & 2.5 & 2.5 \\
\hline Vit. \& Min. mixture1 & 3 & 3 & 3 & 3 \\
\hline Sum & 100 & 100 & 100 & 100 \\
\hline \multicolumn{5}{|c|}{ Proximate analysis (dry matter basis) } \\
\hline Crude protein $(\mathrm{CP})$ & 38.59 & 38.56 & 38.54 & 38.51 \\
\hline Ether extract (EE) & 7.64 & 7.71 & 7.68 & 7.73 \\
\hline Crude fiber $(\mathrm{CF})$ & 9.89 & 9.82 & 9.81 & 9.75 \\
\hline Ash & 10.87 & 10.68 & 10.62 & 10.63 \\
\hline Digestible energy $(\mathrm{Kcal} / \mathrm{kg})$ & 2966 & 2948 & 2931 & 2922 \\
\hline \multicolumn{5}{|l|}{ Each $40 \mathrm{~g}$ contains } \\
\hline $\begin{array}{l}\text { * vit } \mathrm{A} \quad 200000 \mathrm{I} . \mathrm{U} . \\
\text { vit } \mathrm{B} 1 \quad 15 \mathrm{mg} \\
\mathrm{Zn} 1800 \mathrm{mg}\end{array}$ & $\begin{array}{l}\text { vit D3 } 30000 \mathrm{I} . \mathrm{U} \\
\text { vit B2 } 12 \mathrm{mg} \\
\text { Folic Acid } 2 \mathrm{mg}\end{array}$ & $\begin{array}{c}\text { vit } \mathrm{E} \quad 250 \mathrm{mg} \\
\text { vit B12 } 250 \mathrm{mg} \\
\text { vit B6 } 20 \mathrm{mg}\end{array}$ & \multicolumn{2}{|c|}{$\begin{array}{l}\text { vit K3 } 50 \mathrm{mg} \\
\text { Niacin } 15 \mathrm{mg}\end{array}$} \\
\hline ** $\mathrm{Fe} 1200 \mathrm{mg}$ & Bantothonic $80 \mathrm{mg}$ & $\mathrm{Mn} .2400 \mathrm{mg}$ & \multicolumn{2}{|c|}{ Copper 200 mg } \\
\hline
\end{tabular}


The fish were grouped into four diets with L-carnitine (Arab Company for Pharmaceutical \& Medical Plants-MEPACO- Egypt). The basal diet divided into four parts and L-carnitine and its precursors were added to formulate 4 diets as follow:

Group (1): control group (without supplementation of i.e. 0 L-carnitine).

Group (2): was supplemented with $300 \mathrm{mg}$ L-carnitine.kg basal diet.

Group (3): was supplemented with $600 \mathrm{mg}$ L-carnitine.kg basal diet.

Group (4): was supplemented with $900 \mathrm{mg}$ L-carnitine.kg basal diet.

Eggs striping:

At Middle of April month when water temperature reached $28 \pm 2^{\circ} \mathrm{C}$ the fish were striping their eggs. The eggs produced were collected by decreasing the water column of each pond about $50 \mathrm{~cm}$. after that, O. niloticus females were transported via small scoop into small plate containing water. As a consequence, to the fright stress, each mother threw its eggs into the plate. Then, the eggs of each female were collected, and their measurements were recorded. The eggs were collected from the mouth of females after fertilization and weighted and counted and then were put in jars (one jar per female) until hatching and allocated in its ponds of fry until end of treatment (30 days). The eggs were hatched using the available water system. The eggs production was repeated and continued throughout the hatching season.

\section{Records maintained:}

The measurements used in this study were females weight (FW), average of egg weight $(E W / F)$ spawned per female of Nile tilapia was determined by gram. Number of eggs per gram eggs weight $(\mathrm{NE} / \mathrm{G})$ was determined by weighting one gram of eggs then all eggs presented in this gram weight were counted. Weight of eggs in gram per $\mathrm{kg}$ live body weight was calculated by dividing the weight of eggs spawned per female on its live body weight.

The absolute and relative fecundity was determined according to Bhujel (2000) as follows:

Absolute fecundity $(\mathrm{ABS})=$ total weight of eggs per female $(\mathrm{g}) \times$ number of eggs in one gram.

Relative fecundity $($ REL $)=$ absolute fecundity / body weight $(\mathrm{g})$.

Fertilizability was determined by counting the number of fertile eggs in sample as a percentage of the total number in the same sample.

Hatchability $($ HAT $)=\quad \frac{\text { Number of fry obtained per female } \times 100}{\text { Total number of fertilized eggs spawned per female }}$

Growth performance parameters $\boldsymbol{O}$. niloticus fry:

Growth performance:

Records of live body weight $(\mathrm{g})$ of fries were measured about 100 fry for each pond and registered every 14 days (two weeks) during the experimental period. Growth performance parameters were measured by using the following equations:

Specific Growth Rate (SGR):

$$
\mathbf{S G R}=\frac{\mathrm{LnW} 2-\mathrm{LnW} 1}{\mathrm{t}} \times 100
$$

Where: -

$\mathrm{Ln}=$ the natural $\log$

$\mathrm{W} 1$ = first fish weight

$\mathrm{W} 2$ = the following fish weight in "grams" and

$\mathrm{t}=$ period in days. 
Daily Weight Gain (DWG):

$\mathrm{DWG}=\frac{\text { Total weight gain }}{\text { Period (day) }}$

Where :

Total weight gain $=$ final weight $(\mathrm{g})-$ initial weight $(\mathrm{g})$

Feed Efficiency Parameters:

Feed Conversion Ratio (FCR):

A lower value indicates an improved outcome. Feed conversion ratio was calculated by the equation:

FCR $=$ Feed intake $(\mathrm{g}) /$ Weight gain $(\mathrm{g})$

Protein Efficiency Ratio (PER):

PER is probably the most widely method used for valuating protein quality in fish. PER was measured by the following equation:

PER $=$ Weight gain $(\mathrm{g}) /$ Protein intake $(\mathrm{g})$.

\section{Statistical analysis:}

The statistical analysis of date was carried out by applying the computer program, sas (1996) by adopting the following model: -

$\mathbf{Y}_{\mathrm{ijk}}=\boldsymbol{\mu}+\mathbf{R}_{\mathrm{i}}+\mathbf{E}_{\mathrm{ik}}$

Where:

$\mathrm{Y}_{\mathrm{ik}}=$ the $\mathrm{K}$-th observation of the $\mathrm{i}$-th treatment.

$\mu=$ overall mean

$R_{i}=$ the effect of $j$-th treatment

$\mathrm{E}_{\mathrm{ik}}=$ random error assumed to be independently randomly distributed $\left(0, \delta^{2} \mathrm{e}\right)$

Differences among means were tested for significance according to Duncan's multiple range test (1955).

\section{RESULTS AND DISCUSSION}

\section{Reproductive performance for $\boldsymbol{O}$. niloticus females:}

The results were indicated in table 3 for female weight $(\mathrm{g})$ and total egg weight (g) per female $(\mathrm{EW} / \mathrm{F})$ as affected by L-carnitine different levels on hatching are presented in Table (3). The averages of FW were 285.56, 290.34, 293.58 and 287,49g and $\mathrm{EW} / \mathrm{F}$ were $6.75,7.67,8.17$ and $7.80 \mathrm{~g}$ for the four treatments control, 300, 600 and $900 \mathrm{mg} \mathrm{L}$-carnitine per $\mathrm{Kg}$ diet, respectively.

These results indicate that, no significant differences recorded by effect of Lcarnitine levels on body weight of females. while, EW/F for $600 \mathrm{mg} / \mathrm{kg}$ diet was higher than that obtained in control, 300 and $900 \mathrm{mg} \mathrm{L}$ - carnitine per $\mathrm{kg}$ diet. The differences between the means of each of EW/F were non-significant (Table 3).

Table 3: Effect of dietary L-carnitine supplements on reproductive performance for Nile tilapia.

\begin{tabular}{cccccc}
\hline Variable & No. & control & D1 & D2 & D3 \\
\hline (FW) & 30 & $285.55 \pm 3.19$ & $290.34 \pm 2.36$ & $293.53 \pm 4.75$ & $287.50 \pm 3.46$ \\
EW/F & 30 & $6.75 \pm 0.21 \mathrm{~b}$ & $7.67 \pm 0.23 \mathrm{~b}$ & $8.17 \pm 0.22 \mathrm{a}$ & $7.80 \pm 4.11 \mathrm{~b}$ \\
Abs & 30 & $532.70 \pm 16.62 \mathrm{~b}$ & $669.04 \pm 21.84 \mathrm{a}$ & $706.99 \pm 20.97 \mathrm{a}$ & $659.43 \pm 16.69 \mathrm{a}$ \\
Rel & 30 & $1.83 \pm 0.065 \mathrm{c}$ & $2.46 \pm 0.1 \mathrm{~b}$ & $2.53 \pm 0.091 \mathrm{a}$ & $2.33 \pm 0.057 \mathrm{~b}$ \\
NE/GF & 30 & $1.83 \pm 0.065 \mathrm{c}$ & $2.46 \pm 0.1 \mathrm{~b}$ & $2.54 \pm 0.091 \mathrm{a}$ & $2.33 \pm 0.55 \mathrm{~b}$ \\
Hat & 30 & $73.72 \pm 1.54 \mathrm{~b}$ & $78.56 \pm 1.70 \mathrm{a}$ & $78.77 \pm 1.82 \mathrm{a}$ & $76.69 \pm 1.81 \mathrm{a}$ \\
FN/F & 30 & $349.57 \pm 2.04 \mathrm{bd}$ & $498.12 \pm 2.8 \mathrm{~b}$ & $521.41 \pm 3.90 \mathrm{a}$ & $486.35 \pm 3.05 \mathrm{c}$ \\
FN/G & 30 & $1.20 \pm 0.07 \mathrm{c}$ & $1.85 \pm 0.050 \mathrm{a}$ & $1.82 \pm 0.12 \mathrm{a}$ & $1.72 \pm 0.16 \mathrm{~b}$ \\
\hline
\end{tabular}

+ Means with the same letter in each row are not significantly differences $(\mathrm{P}<0.05)$. 
These results are agreement with Soltan et al., (2016) found that, Dietary Lcarnitine supplementation caused a significant increase in body weight of common carp indicating a higher utilization of the dietary energy and protein for growth. A growth-promoting effect of supplemental dietary L-carnitine has been reported in all L-carnitine different levels (300, 600 and $900 \mathrm{mg} \mathrm{kg}^{-1}$ ) and have generally been explained by increasing utilization of dietary energy resulting from increased in fatty acids oxidation (Becker et al., 1999).

Results presented in Table (3) shows that, averages of absolute fecundity (ABS) as affected by the L-carnitine different levels were 532.71, 669.24, 706.99 and 659.44 for the four levels control, 300, 600 and $900 \mathrm{mg}$ L-carnitine/ $\mathrm{kg}$ diet, respectively, and the differences between means were significant $(\mathrm{p}<0.001)$ and the same trend was also observed for relative fecundity (REL), where the averages were 1.83, 2.46, 2.53 and 2.33 for the four different levels, respectively.

Wahbi and Sangak (2017) found that, the incorporation of supplemented Spirulina diets in tilapia feed favorably influenced, fecundity, GSI, fry production and survival. Spirulina contain significant quantities of protein, lipids and fatty acids which are the main constituents of egg yolk. Also, its essential fatty acids content provide energy for spawning activities. the lipids, essential fatty acids, proteins, vitamins and food additives of fish diet influenced rate of absolute and relative fecundity.

Averages of hatchability percentage as affected by L-carnitine different levels were 73.72, 78.56, 78.77 and $76.69 \%$ for the four levels control, 300, 600 and 900mg L-carnitine, respectively. Guroy et al., (2012), James et al., (2006), James et al., (2009), Vasudhevan and James (2011) and Meng-Umphan (2009) have reported that, Spirulina as food additives enhanced hatchability\% in yellow tail cichlid, Pseudotropheus acei, in goldfish, Carassius auratus, in swordtail, Xiphophorus helleri and bassa fish, Pangasius bocourti, respectively.

Table (3) shows that, the average fry number per fish (FN/F) as affected by Lcarnitine different levels and Number of hatching times are listed in Table (3). As shown in Table (3), the averages fry number per fish (FN/F) as affected by Lcarnitine different levels were 349.57, 498.12, 521.41 and 486.35 fry/fish for the four levels control, 300, 600, and 900mg L-carnitine per kg diet, respectively, and the differences between these averages were significant $(\mathrm{P}<0.001)$. This indicated that, the fry number produced per fish for diet contained $600 \mathrm{mg}$ L-carnitine/kg diet was better than those of other treatments. Soltan et al., (2012) reported that, Dietary protein and L-carnitine has been found to influence seed production in tilapia. An increase in egg production with an increase in L-carnitine levels has been reported for Nile tilapia, O. niloticus (Santiago, et al., 1985) and Taiwanese red tilapia (Chang et al., 1988).

The averages of fry number per gram fish (FN/GF) as affected by L-carnitine different levels and Number of hatching times are presented in Table (3). As shown in table (3) the averages (FN/GF) were 1.20, 1.85, 1.82 and 1.72 for the four levels control, 300, 600 and $900 \mathrm{mg} / \mathrm{kg}$ diet, respectively, and the differences between these averages were significant $(\mathrm{P}<0.001)$. In a study carried out by Wahbi and Sangak (2017) found that, the numbers of fries produced were greater in the Spirulina-fed fish could be attributed to the fatty acids contain of Spirulina. Santiago and Reyes (1993) also stated the important of n-6 fatty acids group specially ARA acid in improving spawning efficiency and fry morphometric characteristics. 


\section{Growth performance for fry.}

As shown in Table (4), the effect of L-carnitine different levels after 2 days the averages of fry body weight were $0.0251,0.0274,0.0257$ and $0.0265 \mathrm{~g}$ for $4 \mathrm{~L}-$ carnitine different levels. While, the averages of body weight of fry after 30 days were $0.389,0.406,0.407$ and $0.401 \mathrm{~g}$, respectively, and the differences between averages were significant $(\mathrm{P}<0.001)$ (Tables 4$)$. These results indicated that, the body weight affected by L-carnitine, this may be due to increased lipid oxidation in fry body weight or the growth performance affected by diets with dietary L-carnitine supplements this is probably due to influenced by other factors in addition to diet composition, such as species differences, developmental stage and husbandry conditions.

Wahbi and Sangak (2017) found that, the weight and length of produced fries were greater in the Spirulina-fed fish could be attributed to the fatty acids contain of Spirulina.

Table 4: Effect of dietary L-carnitine supplements on growth performance for Nile tilapia fry.

\begin{tabular}{lccccc}
\hline Variable & No. & control & D1 & D2 & D3 \\
\hline Initial weight & & $0.0251 \pm 0.001$ & $0.0274 \pm 0.001$ & $0.0257 \pm 0.001$ & $0.0265 \pm 0.001$ \\
Final weight & 30 & $0.389 \pm 0.001 \mathrm{c}$ & $0.406 \pm 0.002 \mathrm{a}$ & $0.407 \pm 0.001 \mathrm{a}$ & $0.401 \pm 0.001 \mathrm{~b}$ \\
DWG (2-30 D) & 30 & $0.0129 \pm 0.0001 \mathrm{~b}$ & $0.0136 \pm 0.0001 \mathrm{a}$ & $0.0137 \pm 0.0001 \mathrm{a}$ & $0.0133 \pm 0.0001 \mathrm{a}$ \\
SGR (2-30 D) & 30 & $9.75 \pm 0.31 \mathrm{~b}$ & $9.96 \pm 0.02 \mathrm{a}$ & $9.98 \pm 0.24 \mathrm{a}$ & $9.95 \pm 0.31 \mathrm{a}$ \\
FCR (2-30 D) & 30 & $1.27 \pm 0.003 \mathrm{c}$ & $1.29 \pm 0.003 \mathrm{~b}$ & $1.31 \pm 0.03 \mathrm{a}$ & $1.31 \pm 0.03 \mathrm{a}$ \\
PER (2-30 D) & 30 & $0.12 \pm 0.001 \mathrm{~b}$ & $0.14 \pm 0.01 \mathrm{a}$ & $0.14 \pm 0.01 \mathrm{a}$ & $0.14 \pm 0.012 \mathrm{a}$ \\
\hline
\end{tabular}

+ Means with the same letter in each row are not significantly differences $(\mathrm{P}<0.05)$.

Results of Daily Weight Gain for fry (DWG) for Nile tilapia fry as affected by L-carnitine different levels during the whole experimental period are illustrated in (Table 4). Averages of DWG during the whole period 2-30 days (Table, 4) as affected by L-carnitine levels were $0.0129,0.0136,0.0137$ and $0.0133 \mathrm{~g}$ for the four treatments. Soltan et al., (2015) found that, the averages of DWG during the period 20-30 days were $0.025,0.026,0.027$ and $0.027 \mathrm{~g}$ for the different levels while the averages of DWG during the same period were $0.03,0.03 \mathrm{~g}$ for the all hatching times and the analysis of variance between averages were significant $(\mathrm{P}<0.05)$ for $\mathrm{L}$ carnitine different levels.

As shown in Table (4), averages of SGR during the whole experimental period 2-30 days as affected by L-carnitine levels were 9.75, 9.96, 9.98 and 9.95 for the four treatments, control, 300, 600 and $900 \mathrm{mg}$ L-carnitine, respectively.

Wahbi and Sangak (2017) stated that, although there were no detected differences in egg morphometric characters, the specific growth rate of fries from fish fed on the Spirulina supplemented diets was higher compared to control that may be attributed to high Spirulina content of essential amino acids, fatty acids and vitamins that influence the growth performance of fish.

As shown in Table (4), averages of FCR during the whole experimental period 2-30 days as affected by L-carnitine levels were 1.27, 1.29, 1.31 and 1.31 for the four L-carnitine levels control, 300, 600 and $900 \mathrm{mg}$ L-carnitine, respectively. Vasudhevan and James (2011) reported that, L-carnitine as food additives enhanced Feed Conversion Ratio for fry produced in goldfish Carassius auratus.

As presented in Table (4), averages of PER during the whole experimental period 2-30 days as affected by the L-carnitine different levels were $0.12,0.14,0.14$ and 0.14 for the four treatments control, 300, 600 and $900 \mathrm{mg}$ L-carnitine, respectively. These results were indicated that, L-carnitine at levels 300, 600 and 900mg L-carnitine were improved for PER in Nile tilapia. Schlechtriem et al., (2004) 
he found that, the diets contained the lower L-carnitine level (300 mg kg-1 diet) released the best growth and feed utilization indices PER which did not significantly different from the higher L-carnitine levels (600 and $900 \mathrm{mg} \mathrm{kg}-1 \mathrm{diet}$ ) and these results indicated that, dietary L-carnitine at the lower level $\left(300 \mathrm{mg} \mathrm{kg}^{-1}\right)$ is effective for improving of growth and feed utilization of common carp.

\section{CONCLUSION}

Based on results obtained in this study, it could be concluded that, the Lcarnitine at levels 300 and $600 \mathrm{mg}$ L-carnitine were improved each of reproductive performance aspects and fry performance for Nile tilapia under optimum breeding stocks management that may improve hatcheries production for the commercial scale.

\section{REFERENCES}

Becker, K.; Schreiber, S.; Angoni, C. and Blum, R. (1999). Growth performance and feed utilization response of Oreochromis niloticus $\times$ Oreochromis aureus hybrids to L-carnitine measured over a full fattening cycle under commercial conditions. Aquaculture, 174: 313-322.

Bhujel, R. C. (2000). A review of strategies for the management of Nile tilapia (Oreochromis niloticus) brood fish in seed production systems, especially hapabased systems. Aquaculture, 181: 37-59.

Chang, S. L.; Huang, C. M. and Liao, I. C. (1988). The effect of various feeds on seed production by Taiwanese red tilapia, p. 319-322. In: Pullin, R.S.V., Bhukaswan, T., Tonguthai, K., Maclean, J.L. Eds., The Second International Symposium on Tilapia in Aquaculture, ICLARM Conference Proceedings, 15, Department of Fisheries, Bangkok, Thailand, and International Center for Living Aquatic Resources Management, Manila Philippines, 623 pp.

Chatzifotis, S.; Takeuchi, T. and Seikai, T. (1995). The effect of dietary L-carnitine on growth performance and lipid composition in red sea bream fingerlings. Fish. Sci., 61: 1004-1008.

Dunncan, D. B. (1955). Multiple range and multiple test. Biometerics, 11: 1-42.

El-Saidy, D. M. S. and Gaber, M. M. A. (2005). Effect of dietary protein levels and feeding rates on growth performance, production traits and body composition of Nile Tilapia, (Oreochromis niloticus) (L.) cultured in concrete tanks. Aquac. Res., 36(2): 163-171.

Farag, M. S. (2003). Reproductive performance of Oreochromis niloticus through three seasons on earthen ponds. Egypt. J. Aquat. Biol. \& Fish., 7(4): 263 - 282.

Fath El-Bab, A. F.; Farag, M. E.; Ramadan, A. A. and Hassan, A. S. (2011). Effect of temperature and female weight on reproductive performance of two Nile tilapia (Oreochromis niloticus) populations Egypt. J. Aquat. Biol. \& Fish., 15 (2): 179193.

Gómez-Márquez, J. L.; Peña-Mendoza, B.; Salgado-Ugarte, I. H. and GuzmánArroyo, M. (2003). Reproductive aspects of Oreochromis niloticus (Perciformes: Cichlidae) at Coatetelco lake, Morelos, Mexico. Rev. Biol. Trop., 51: 221-228.

Guroy, B.; Sahin, I.; Mantoglu, S. and Kayali, S. (2012). Spirulina as a natural carotenoid source on growth, pigmentation and reproductive performance of yellow tail cichlid Pseudotropheus acei. Aquacult. Int., 20: 869-878. 
Harpaz, S. (2005). L-Carnitine and its attributed functions in fish culture and nutrition-a review. Aquaculture, 249: 3-21.

Hebisha, H. and Fathi, M. (2014). Small and medium scale aquaculture value chain development in Egypt: Situation analysis and trends. World Fish/ILRI Project Report. Nairobi, Kenya: International Livestock Research Institute (ILRI).

James, R.; Sampath, K.; Thangarathinam, R. and Vasudevan, I. (2006). Effect of dietary Spirulina level on growth, fertility, coloration and leucocyte count in red swordtail, Xiphophorus helleri. Isr. J. Aquac-Bamidgeh, 58: 97-104.

James, R.; Vasudhevan, I. and Sampath, K. (2009). Interaction of Spirulina with different levels of vitamin $\mathrm{E}$ on growth, reproduction and coloration in goldfish (Carassius auratus). Isr. J. Aquacult., 61: 330-338.

Ji, H.; Bradiley, T. M. and Tremblay, G. C. (1996). Atlantic salmon (Salmo salar) fed L-carnitine exhibit altered intermediary metabolism and reduced tissue lipid, but no change in growth rate. J. Nutr., 126: 1937-1950.

Kariman, A. Sh; Hanan, M. and Salama. M. (2008). Investigations on some aspects of reproductive biology in Oreochromis niloticus (Linnaeus, 1757) inhabited AbuZabal Lake, Egypt. Global Vet., 2: 351-359.

Kirpichnikov, V. S. (1981). Genetic Bases of Fish Selection. Springer-Verlag, New York, New York.

Macaranas, J. M.; Mather, P. B.; Lal, S. N.; Vereivalu, T.; Lagibalavu, M. and Capra, M. F. (1997). Genotype and environment: a comparative evaluation of four tilapia stocks in Fiji. Aquaculture, 150: 11-24.

Meng-Umphan, K. (2009). Growth performance, sex hormone levels and maturation ability of Pla Pho (Pangasius bocourti) fed with Spirulina supplementary pellet and hormone application. Int. J. Agric. Biol., 11: 458-462.

Mohamed, W. M.; Shehata, S. M. A.; El-Naggar, G. O.; Khater, A. M. M. and Mahmoud, M. K. (2014). Effect of female weight on reproductive performance of Nile Tilapia (Oreochromis niloticus) 4th Conference of Central Laboratory for Aquaculture Research, 315-332.

Mohseni, M.; Ozorio, R. O. A.; Pourkazemi, M. and Bai, S. C. (2008). Effects of dietary L-carnitine supplements on growth and body composition in beluga, $H$. huso, juveniles. J. Appl. Icthyol., 24: 646-649.

Mohseni, M. and Ozorio, R. O. A. (2014). Effects of dietary L-carnitine level on growth and body composition and antioxidant status in beluga (Husohuso L. 1758). Aquaculture Nutrition, 20: 477-485.

Orlando, T. M.; Marinez, M.; Renan, R. P.; Adriano, C. C.; Ivan B. A. and Priscila, V. R. (2017). Reproductive performance of female Nile tilapia (Oreochromis niloticus) fed diets with different digestible energy levels. R. Bras. Zootec., 46 (1): 1-7.

Ozorio, R. O. A.; Booms, G. H. R.; Huisman, E. A. and Verreth, J. A. J. (2002). Changes in amino acid composition in the tissues of African catfish (Clarias gariepinus) as a consequence of dietary L-carnitine supplements. J. Appl. Icthyol., 18(3): 140-147.

Rodehutscord, M. (1995). Effects of supplemental dietary L-carnitine on the growth and body composition of rainbow trout (Oncorhynckus mykiss) fed high-fat diets. J. Anim. Physiol. Anim. Nutr., 73: 276-279.

Santiago, C.B. and Reyes, O. F. (1993). Effects of dietary lipid source on reproductive performance and tissue lipid levels of Nile tilapia Oreochromis niloticus (Linnaeus) broodstock. J. Applied Ichthyol., 9: 33-40. 
Santiago, C. B.; Aladaba, M. B.; Abuan, E. F. and Laron, M. A. (1985). The effects of artificial diets on fry production and growth of Oreochromis niloticus breeders. Aquaculture 47: 193-203.

SAS (1996). SAS procedure Guide "Version 6.12 ed". SAS Institute Inc., Cray, NC, USA.

Schlechtriem, C.; Bresler, V.; Fishelson, L.; Rosenfeld, M. and Becker, K. (2004). Protective effects of dietary L-Carnitine on tilapia hybrids (Oreochromis niloticus $\times$ Oreochromis aureus) reared under intensive pond-culture conditions. Aquaculture Nutrition, 10: 55-63.

Soltan, M. A.; El-Laithy, S. M.; El-Nagaar, G. O. and Mohammed, W. E. (2012). Effect of spawning month, dietary protein and pond protection of fry production of Nile tilapia, Oreochromis niloticus. Egypt. J. Biol. \& Fish., 16(1): 21-32.

Soltan, M. A.; Abdella, M. M.; El-Sayaad, G. A. and Abu-El Wafa, M. H. (2015). Effect of some over-wintering regimes on survival and growth performance of Nile tilapia Oreochromis niloticus. Biological and Chemical Research, 2: 362374.

Soltan, M. A.; AbouZead, M. Y. and Fouad, I. M. (2016). Combined effects of dietary lipid and L-Carnitine on the growth performance and body composition of common carp Cyprinus carpio. Global Veterinaria, 17(5): 451-459.

Vasudhevan, I. and James, R. (2011). Effect of optimum Spirulina with different levels of vitamin $\mathrm{C}$ on growth, reproduction and coloration in goldfish Carassius auratus (Linnaeus, 1758). Indian J. Fish., 58: 101-106.

Wahbi, O. M. and Sangak, Y. (2017). Enhancement of Reproductive Performance of Nile Tilapia Oreochromis niloticus using Phytobiotic Spirulina platensis. J. Biol. Sci., 17 (7): 305-311. 